\title{
CYTOTOXIC AND GENOTOXIC EFFECTS OF AQUEOUS EXTRACTS OF HELICHRYSUM ARENARIUM AND CETERACH OFFICINRUM
}

\author{
Edlira Pajenga*, Albana Pisha, Anastasi Rapi \\ "University of Elbasan "A. Xhuvani”, Faculty of Natural Science, Department of Biology, Elbasan, Albania; \\ "Corresponding Author Edlira Pajenga, e-mail: edlira.pajenga@uniel.edu.al;
}

Received May 2020; Accepted June 2020; Published July 2020;

DOI: https://doi.org/10.31407/ijees10.312

\begin{abstract}
There are several reported works on the possible anticancer activity of drugs obtained from medicinal plants, due to their ability to block the abnormal cell division considered as an engrossing and increscent therapeutic target. The aqueous extract of Helichrysum arenarium and Ceterach officinrum were prepared with tap water as is done usually by unhealthy outpatients. The aim of this study was to estimate the potential cytotoxicity and genotoxicity of these plants in Allium cepa. Small bulbs were submerged in tap water for 4 days exposed to $5 \mathrm{gr} / 1,10 \mathrm{gr} / \mathrm{l}, 20 \mathrm{gr} / \mathrm{l}$ and 80 $\mathrm{gr} / \mathrm{l}$ extracts prepared for macroscopic and microscopic analyses, respectively. Tap water was used as negative control. Fragments of roots tip were treated with acetoorcein, then clamped vial with acetic acid. The slides were prepared by squashing and the samples were analyzed under a light microscope. At all concentrations, the extracts inhibit root growths compared with the negative control and was statistically significant $(\mathrm{p}<0.05)$. The mitotic index decreased owing to increasing concentration at both plants extracts, reaching a maximum percent inhibition of $94 \%$ at Helichrysum arenarium which showed the highest percent of abnormal cells at the same time. These results show that although their antiproliferative activity give them anticarcinogenic properties but by augmenting the amount of these plants used we may be exposed to genotoxic effects on organism.
\end{abstract}

Keywords: medical plant, Allium cepa, mitotic index, anticarcinogenic, genotoxic. 